Article

\title{
The Impact of Relationship Trust, Environmental Protection Awareness, and Regenerative Innovation on Environmental Performance: A Case Study of the Industrial Waste Industry
}

\author{
Wen-Chih Yeh ${ }^{1}$, Ming-Hsun Tseng ${ }^{2}$, Chun-Chang Lee ${ }^{3, *}$ and Cheng $\mathrm{Yu}^{3}$ \\ 1 Department of Real Estate Management, HungKuo Delin University of Technology, New Taipei City 23654, \\ Taiwan; wen00126@mail.hdut.edu.tw \\ 2 Department of Real Estate \& Built Environment, National Taipei University, New Taipei City 23741, Taiwan; \\ minghsun@mail.ntpu.edu.tw \\ 3 Department of Real Estate Management, National Pingtung University, Pingtung 90004, Pingtung County, \\ Taiwan; 107257035@nccu.edu.tw \\ * Correspondence: lcc@mail.nptu.edu.tw
}

Received: 11 February 2020; Accepted: 24 March 2020; Published: 2 April 2020

check for updates

\begin{abstract}
In order to expand on the scope of research on partnership governance, this study explored the impact of relationship trust, stakeholder environmental awareness, and regenerative innovation on environmental performance. The study participants were primarily employees of legitimate public waste disposal and treatment facilities in the six special municipalities of Taiwan (including domestic and overseas facilities). The investigation was conducted via a questionnaire survey. A total of 1000 questionnaires were distributed and 550 were recovered, of which 539 were valid, indicating an effective recovery rate of $53.9 \%$. Data analysis was conducted by structural equation modeling. The empirical results showed that relationship trust had a significant and positive impact on stakeholders' environmental awareness, which, in turn, had a significant and positive impact on regenerative innovation. Relationship trust had no direct and significant impact on regenerative innovation. Hence, the impact of relationship trust on regenerative innovation is mediated by stakeholders' environmental awareness. The results also showed that regenerative innovation had a significant and positive impact on environmental management performance, and no significant impact on environmental operational performance. Hence, the impact of regenerative innovation on environmental management performance is not mediated by environmental operational performance.
\end{abstract}

Keywords: environmental protection awareness; relationship trust; regenerative innovation; environmental performance; industrial waste industry

\section{Introduction}

When people began to realize the connection between environmental pollution and safety, the relationship between pollution arising from corporate production and the safety of the living environment became more pronounced. Therefore, people's awareness, awakening, and reflection with regard to environmental issues have sparked a rethinking of environmental issues. Studies on companies and natural environment issues have emerged in great numbers since 1990. By the mid-1990s, empirical research on organizations and the natural environment, as well as research on environmental policy and environmental performance, also began to emerge [1,2].

With increasingly close interactions between the external environment and corporate organizations, the latter can no longer avoid becoming connected to the former, as they cannot survive independently 
in isolation from other organizations, so environmental features are an important influencing factor for the organization's operations. When management and organizational strategies are constantly being updated and proposed, the way to ultimately achieve a symbiosis with the environment is to overcome existing challenges through innovation. Bloom and John [3] believe that any industry in a dynamic market environment needs to stabilize its market through innovation activities in order to compete and survive under the pressure of consumers and lawmakers [4]. Previously, Taiwanese companies have only focused on economic development; the environmental conservation efforts of companies were only carried out under external and internal pressures. In addition, environmental regulations in various countries are becoming more and more stringent, leading companies to face green competition. Therefore, the innovation and transformation that occur in different industries are also different. The innovation of the industrial waste industry is different from the innovation and R\&D model of other industries, as the industry is faced with the regenerative innovation capability of products, which involves the innovation in front- and back-end regenerative manufacturing, management innovation within the organization, and service innovation at the sales end. Regenerative innovation consists of manufacturing, management, and service innovation. Manufacturing innovation refers to a company's ability to enhance its production by increasing its efficiency and capabilities. Management innovation refers to changes in a company's organizational structure or administrative procedures [5]. Service innovation refers to a company's ability to constantly formulate and update its service-based strategies in order to increase its service quality and achieve customer satisfaction [6]. This study conducted follow-up research on, and an analysis of, regenerative innovation.

Environmental issues are related to public affairs. The stakeholders of issues become the key to whether the issues can be addressed further. Freeman's [7] research on stakeholders has become a noteworthy school of thought in management research [8]. However, all stakeholders and companies must share a common topic for a certain issue. Aside from environmental improvement, environmental awareness must be consistent in order to achieve consensus and boost environmental performance. The stakeholders involved in environmental awareness within the industry include staff members of all levels within the organization, consumers, the government, competitors, and environmental groups [9]. Therefore, in the first step of establishing a long-term strategy, it is necessary to clarify and understand the environmental demands of stakeholder environmental awareness in companies, and to build up a rapport with one another through the establishment of relationship trust. This is because stakeholders' environmental awareness can express their interests through direct pressure or information dissemination, which, in turn, affect the organization's innovation and environmental performance results [10].

Relationship trust may exist between individuals or organizations. When trust between members of an organization increases, it also strengthens the connection between members within the organization, and fosters relationships of trust between members. The establishment of trust can act as a bridge to link stakeholders' environmental awareness between enterprises, as well as a bonding agent between partnerships. Morgan and Hunt [11] noted that trust exists in the form of ones confidence in the credibility and trustworthiness of trading partners. If consumers believe that the representative is honest and trustworthy or can fulfill the tasks with which they have been entrusted, the trust within the consumer's mind can overcome risks and uncertainty, that is, the greater the degree of environmental uncertainty, the more important trust becomes.

Environmental performance is an indicator for companies' use of resources, and covers performance in terms of minimizing the use of pollutants, saving energy, reducing waste, saving resources, reducing environmental risks, producing harmless products, and exposing potential environmental risks. In recent years, researchers have discussed many aspects of how companies can improve their environmental performance. Papadopoulos and Giama [2] and Chien and Shih [12] believe that it is necessary for companies with start with their internal management and operational procedures, and use environmental performance as an evaluation indicator. In terms of environmental operational performance, it is necessary to reduce the use of resources as much as possible; improvement 
must begin with internal management procedures, environmental equipment design, industry pollution prevention, and other hardware-related factors. Environmental management performance must be enhanced in accordance with environmental policies and measures; it is necessary to strengthen support at the management level and focus on improving social relations and the corporate image, as well as improving environmental management information, reducing antipollution costs, improving the effectiveness of environmental protection and industry safety management, and improving staff education and training, with the ultimate goal of making decisions and taking action aimed at achieving environmental sustainability. In light of this, the environmental awareness of each stakeholder must be enhanced in order to achieve the goal of corporate sustainability, as it often influences the formulation of environmental protection policies in Taiwan. Therefore, in terms of physical facilities, measures should be taken to reduce waste during production, improve the efficiency of environmental equipment, and reduce pollution. With regard to organizational members, companies should constantly implement relevant in-service training programs in accordance with the implementation of national policies on environmental protection in industry, so as to foster new environmental knowledge among the stakeholders and give rise to new concepts. This not only improves the organizational members' trust toward their company, but also fosters their unity, which facilitates the enhancement of environmental performance.

Interestingly, the issue of transaction costs has a crucial influence on the industrial waste industry. Yeh et al. [13] focused on transaction costs and investigated partnerships and resource dependencies based on the five variables, i.e., data collection costs, supervision costs, adjustment costs, committed costs, and execution costs. The results revealed that transaction costs did not have a significant negative effect on partnerships. On the other hand, a previous study found that an increase in transaction costs hindered companies in terms of their ability to maintain partnerships [14]. Meanwhile, resource dependency was found to have a significant positive effect on transaction costs, with low resource dependency indicating that a company possesses comparatively plentiful information and resources, which can reduce resource dependency costs [15].

This study explored and analyzed the impact of stakeholder environmental awareness, relationship trust, and regenerative innovation on environmental performance. The research objectives are as follows: (1) to explore whether the impact of relationship trust on regenerative innovation is mediated by stakeholder environmental awareness; and (2) to explore whether the impact of regenerative innovation on environmental management performance is mediated by environmental operational performance.

\section{Theoretical Background}

\subsection{Stakeholders}

Freeman [7] defines stakeholders as groups or individuals who can influence or be influenced by others in the process of achieving organizational goals. As the stakeholders concerned with environmental issues include the government, consumers, and competitors, all stakeholders should jointly help to shape the social mechanism conducive to the promotion of environmental efforts by companies, and companies themselves should work hard in joining hands with stakeholders including consumers, the government, competitors, and environmental groups to establish relationship trust, so as to identify and balance the environmental needs of different stakeholders. These are precisely the developments and challenges that modern companies should take on [9].

Henriques and Sadorsky [10] divided stakeholders into three categories: (1) internal (senior executives, mid-level executives, and junior employees); (2) socio-economic (legislators and environmental groups); and (3) market (consumers and potential competitors). Studies on stakeholders and environmental issues have indicated that each has a mutual positive impact on one the others. Kao and Huang [16] studied 1000 manufacturing industries in Taiwan through empirical analysis and found that companies' environmental management (green management) is positively correlated with various stakeholders including regulations, organizations, and communities. Pressures from 
consumers, government regulations, and local residents and environmental groups also have a positive impact on the formation of companies' environmental plans [17]. As stakeholders will run into the issue of opposing for the sake of opposing out of their own interests, we integrated stakeholder and company awareness into the singular term "environmental awareness", and defined it as stakeholders' green environment awareness. The views of stakeholders and companies towards events can only resonate when their beliefs align. In the latter part of this study, some of the relevant stakeholders were integrated into the term "environmental awareness".

\subsection{Relationship Trust}

Trust is a very important issue in organizational behavior. Morgan and Hunt [11] believe that the success of long-term partnerships depends on mutual trust. The greater the trust, the greater the commitment to work, and therefore, the higher the level of trust among the members of the organization, the more smoothly communication can be conducted, and the better the performance and quality of decision-making between groups [4]. When the level of trust between two parties is higher, both parties can naturally foster cooperation, reduce transaction costs, and enhance one another's capabilities [18]. Relationships of trust between organizations are helpful towards strengthening the reliability and suitability of the relationship between companies. Jap [19] believes that trust is manifested in customer confidence in the righteousness (honesty and trustworthiness) and credibility (task fulfillment) of the business representative.

\subsection{Regenerative Innovation}

In order to focus on the attributes of the industrial waste industry, this study termed the research and development of regenerative systems "regenerative innovation." The analysis of the three aspects of front- and back-end manufacturing, i.e., innovation, management innovation within the organization, and service innovation on the sales end, is as follows: (1) Manufacturing innovation: Schilling [20] believes that manufacturing innovation is primarily aimed at improving the production efficiency and capability of companies, with the main goal of improving production yield. Macher and Mowery [21] noted that companies wishing to obtain sustainable competitive advantages can do so by bringing in new manufacturing technology or developing new manufacturing processes. Through innovation, manufacturers can increase the speed with which products enter the market, thereby increasing production efficiency and reducing production costs. (2) Management innovation: Abernathy and Kim [22] believe that the impact of management innovation on product systems is different from that of innovation on customers and markets. Different kinds of innovation require different operational environments and environmental management skills. Lin et al. [5] proposed that management innovation refers to changes in an organization's structure or administrative procedures, such as employee recruitment and resource allocation. (3) Service innovation: Paton and McLaughlin [6] noted that service innovation involves activities related to services, with a focus on improving service quality and achieving customer satisfaction through innovative service strategies such as after-sales services, product warranty, or routine maintenance. Service innovation is a way for companies to provide better services so that they may gain a sustainable competitive advantage.

\subsection{Environmental Performance}

In previous research related to environmental performance, most early sources of information came from the Council on Economic Priorities (CEP), a nonprofit organization focused on environmental performance analyses of high-polluting industries in the US, such as the oil, steel, pulp, and paper production industries. Measurements of antipollution performance are primarily based on companies' pollution emissions. Subsequent scholars have used the US's toxic substances release inventory to measure environmental performance. Recently, many scholars have begun to look into antipollution studies conducted by companies themselves, specifically analyzing the two evaluation indicators of environmental operational performance and environmental management performance. 
A comprehensive analysis of environmental performance by Papadopouls and Giama [2] and Chien and Shih [12] divided environmental performance into environmental operational performance and environmental management performance. (1) Environmental operational performance covers energy management, material consumption, assessments of the organization's physical environment, and waste emissions. (2) Environmental management performance reflects the management's efforts to improve the environmental operational performance of the organization. It is helpful for evaluating management effectiveness and improving the results of decisions and actions for environmental performance.

\section{Literature Review and Establishment of Study Hypotheses}

\subsection{Relationships among the Factors of Relationship Trust, Stakeholder Environmental Awareness, and Regenerative Innovation}

Industry organizations were able to build bridges of trust only after expanding their connections through their respective social networks. When manufacturers can maintain control over a strategy based on trust, they can then establish a positive relationship with their partners and urge one another to move towards innovation and R\&D to increase their market share and profits [23]. A study by Cheng et al. [24] on the R\&D departments of the electronics industries listed on the market in Taiwan shows that when employees have established trust in their superiors, they can effectively and positively influence product R\&D and innovation. Therefore, we proposed the following hypothesis:

Hypothesis 1 (H1): Relationship trust has a significant and positive impact on regenerative innovation.

Industry organizations consist of stakeholders of different levels (such as staff of all levels within the organization, consumers, the government, competitors, and environmental protection groups). As every party has a different perspective, there is both potential for cooperation and threat among stakeholders. However, trust can regulate relationships among stakeholders. When trust among stakeholders is higher, one can naturally work with another party with ease. Therefore, a high level of trust among organizations will lead to the exchange of knowledge and sharing of confidential information among various stakeholders [25], as well as suppressing the possibility of speculative action, which will make it possible to develop long-term and stable relationships. Therefore, we proposed the following hypothesis:

Hypothesis 2 (H2): Relationship trust has a significant and positive impact on stakeholder environmental awareness.

In stakeholder environmental awareness within the industry, managers believe that although the cost of carrying out environmental programs is great, the cost of not doing so is even greater. Stakeholders should understand that living up to duties in terms of environmental efforts and innovation will be helpful toward promoting corporate innovation and $R \& D$, as well as improving the external environment. Petts and Mary [26] studied four potentially polluting industries in the United Kingdom (i.e., chemical, engineering, food manufacturing, and textile) and explored the relationship between environment sustainability and corporate culture. They found from 387 valid samples that there was a significant and positive relationship between stakeholders' attitudes and beliefs towards social responsibility and corporate innovation and R\&D, and that this impact can boost subsequent industry innovation, thereby stimulating companies to enact innovative and revolutionary antipollution efforts. Therefore, we proposed the following hypothesis:

Hypothesis 3 (H3): Stakeholder environmental awareness has a significant and positive impact on industry regenerative innovation. 
3.2. Relationship of Regenerative Innovation with Environmental Operational Performance and Environmental Management Performance

In addition, empirical research on regenerative innovation and environmental management performance showed that when regenerative innovation was linked to administrative procedures in environmental management and basic production activities, environmental management performance was more pronounced [27]. Klassen and Whybark [28] examined the old furniture recycling industry of the US and found that the innovation and R\&D of recycled products have a positive impact on environmental management. When management information is abundant, aside from reducing production costs, decision-making, planning, and management can be more effectively achieved. In their study on farmland pollution events caused by industrial waste, Fan and Chiu [29] mentioned that regenerative innovation is an important issue to the overall waste industry, as the means of achieving comprehensive management of the entire resource recycling and reuse system, as well as utilizing advanced technologies to improve the value of products and prevent potential pollution, are all beneficial for enhancing environmental performance. Therefore, we proposed the following hypothesis:

Hypothesis 4 (H4): Regenerative innovation has a significant and positive impact on environmental management performance.

Nehrt [30] divided pollution control into two kinds of preventive control, namely ex post and ex ante. Ex post control involves the treatment of pollutants such as wastewater, waste gas emissions, and solid waste using pollution control equipment, with the aim of meeting the management and control standards of environmental regulations. Ex ante prevention involves resolving pollution issues at the source, with the aim of improving environmental performance through cleaner production operations. Whether it is achieved by ex ante or ex post improvement, better environmental performance must involve innovation and R\&D, as they form the driving forces behind environmental operational improvement [31]. Shrivastava [32] believes that companies can achieve better environmental operational performance and competitive advantages through the development of environmental technology innovation (regenerative innovation), and reduce pollution through innovation and R\&D. Therefore, we proposed the following hypothesis:

Hypothesis 5 (H5): Regenerative innovation has a significant and positive impact on environmental operational performance.

Nehrt [30] believes that the new ways of reducing pollution cover two aspects, i.e., hardware (facilities, equipment, and processes) and operational methods (recycling of raw materials and product design), with the aim of creating new market needs, as well as reducing costs while taking care of antipollution at the same time, so as to achieve more efficient energy usage and reduce waste output, thereby saving costs and improving corporate image [31]. When the management, maintenance, and design of environmental operations begin to be implemented, costs can be reduced for subsequent environmental management, so as to promote sustainable environmental development [33]. Therefore, we proposed the following hypothesis:

Hypothesis 6 (H6): Environmental operational performance has significant and positive impact on environmental management performance.

\section{Study Design}

\subsection{Study Framework}

The framework of this study is shown in Figure 1. This study explored the relationships of influence among the factors of relationship trust, stakeholder environmental awareness, and regenerative 
innovation on environmental performance (operational performance and management performance). The descriptions of the measurement variables for each aspect are shown in Table 1.

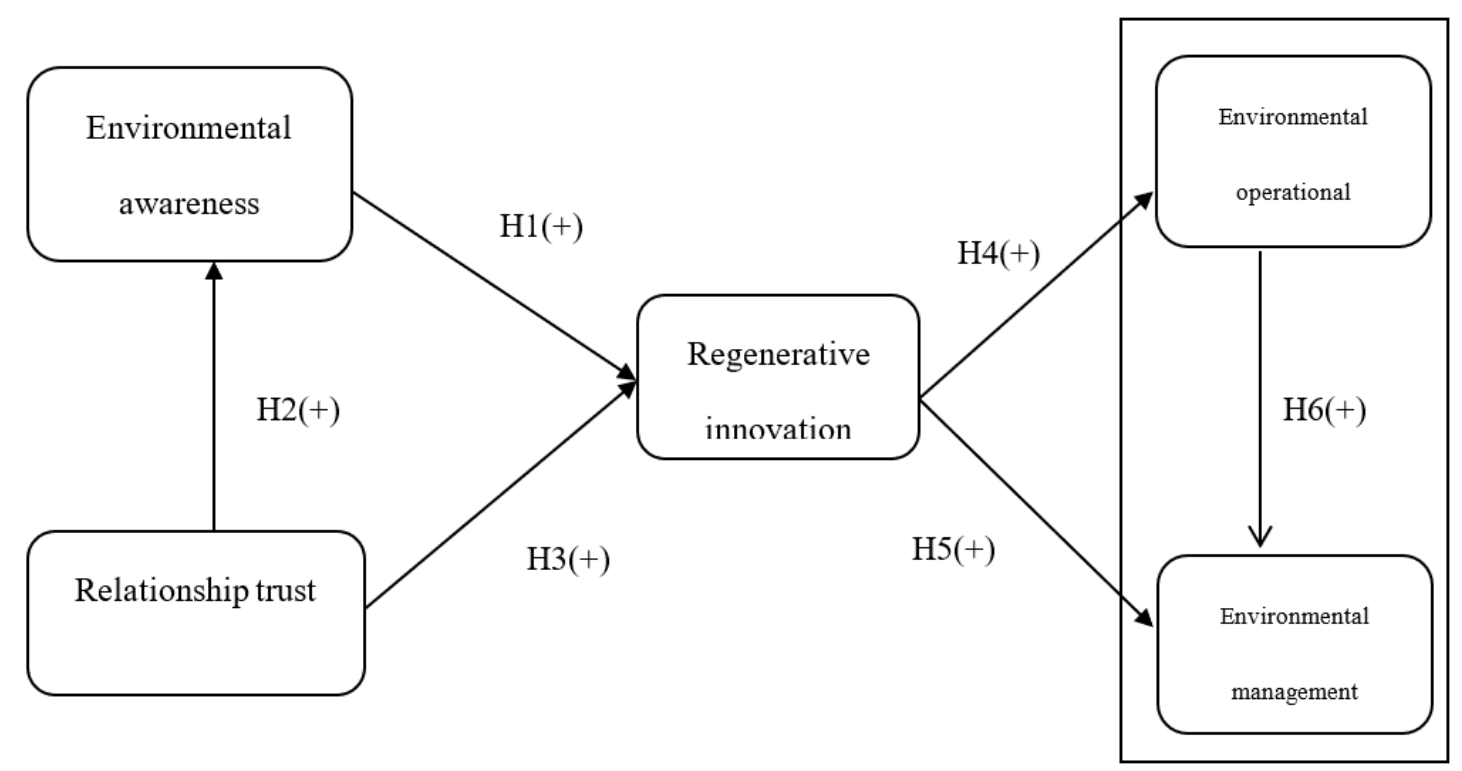

Figure 1. Environmental performance study framework.

\subsection{Operational Definitions of Variables}

In terms of stakeholder environmental awareness, Freeman [7] and Henriques and Sadorsky [10] divided organizations' relevant stakeholders into three categories: Internal, socioeconomic, and market stakeholders. As the relevant stakeholders have different views on environmental awareness, and each group will handle it in the way that best serves their own interests, they will express their interests and views through direct or indirect pressure, and strategically manage companies in this way. Indeed, external environmental awareness, such as awareness of urgent environmental issues, will also influence the environmental awareness of the relevant stakeholders. Therefore, environmental awareness was measured by these three subaspects in this study.

In terms of relationship trust, this is an important issue where the relationship between stakeholders and companies (managers) is involved. In this study, this aspect is assessed through two variables, i.e., trustworthiness and ability to fulfill tasks, represented by company managers [11,34,35].

In terms of regenerative innovation, innovation efforts by companies through their work processes can be divided into three levels. The first is the manufacturing and production process. This is the most important stage in antipollution efforts, and it is necessary to carry out manufacturing innovation. Following manufacturing innovation, a series of innovation and R\&D efforts can be implemented through internal management and end-point sales services to improve environmental performance. In this study, regenerative innovation is measured by three subaspects: manufacturing innovation [36], management innovation [5], and service innovation [6]. 
Table 1. Operational definitions of variables.

\begin{tabular}{|c|c|c|c|c|}
\hline Aspect & Factor & Variable & Definition & Reference \\
\hline Environmental awareness & - & $\begin{array}{l}\text { Internal stakeholders } \\
\text { Socioeconomic stakeholders } \\
\text { Market stakeholders }\end{array}$ & $\begin{array}{l}\text { Senior executives, mid-level executives, and junior employees can pledge their } \\
\text { commitment to improve environmental management as well as extend support and } \\
\text { participate in environmental issues. } \\
\text { The government and environmental groups can use market-based legal tools to induce } \\
\text { companies to invest in more innovative solutions, as well as adopt the use of education } \\
\text { or moral persuasion to push for environmental problems to be resolved. } \\
\text { Consumers as well as domestic and overseas competitors will boycott or reject } \\
\text { manufacturers for not paying attention to environmental issues. }\end{array}$ & $\begin{array}{l}\text { Freeman [7]; Henriques and } \\
\text { Sadorsky [10] }\end{array}$ \\
\hline Relationship trust & - & $\begin{array}{l}\text { Honesty and } \\
\text { trustworthiness } \\
\text { Task fulfillment }\end{array}$ & $\begin{array}{l}\text { Partner business representatives are honest, righteous, and trustworthy. } \\
\text { Partner business representatives complete tasks responsibly and generously. }\end{array}$ & $\begin{array}{l}\text { Morgan and Hunt [11]; Doney } \\
\text { and Cannon [34]; Cheng [35] }\end{array}$ \\
\hline Regenerative innovation & - & $\begin{array}{l}\text { Production innovation } \\
\text { Management innovation } \\
\text { Service innovation }\end{array}$ & $\begin{array}{l}\text { Companies can manufacture the same amount of goods and conduct antipollution } \\
\text { processes while investing less resources within a shorter duration. } \\
\text { Changes are enacted in the organization's structure or administrative processes (staff } \\
\text { recruitment, resource allocation, and education and training). } \\
\text { Improving service quality, meeting customer needs, and improving } \\
\text { customer satisfaction. }\end{array}$ & $\begin{array}{l}\text { Rehfeld et al. [37] } \\
\qquad \text { Lin et al. [5] } \\
\text { Paton and McLaughlin [6] }\end{array}$ \\
\hline \multirow{2}{*}{ Environmental performance } & $\begin{array}{l}\text { Operational } \\
\text { performance }\end{array}$ & $\begin{array}{l}\text { Management procedures } \\
\text { Maintenance operations } \\
\text { Equipment design }\end{array}$ & $\begin{array}{l}\text { Revising the various environmental work processes involved in } \\
\text { organizational operations. } \\
\text { Maintenance operations of industry antipollution efforts, the greenhouse effect, and } \\
\text { wastewater treatment input, output, and operational projects. } \\
\text { Carrying out design and planning for environmental equipment. }\end{array}$ & $\begin{array}{l}\text { Papadopoulos and Giama [2]; } \\
\text { Chien and Shih [12] }\end{array}$ \\
\hline & $\begin{array}{l}\text { Management } \\
\text { performance }\end{array}$ & $\begin{array}{l}\text { Management information } \\
\text { Production cost } \\
\text { Environmental } \\
\text { sustainability }\end{array}$ & $\begin{array}{l}\text { Providing organizations with information that is helpful towards improving } \\
\text { environmental management. } \\
\text { Reducing production costs and improving the effectiveness of environmental protection } \\
\text { and industry safety management. }\end{array}$ & \\
\hline
\end{tabular}


In terms of environmental performance, through the improvement of hardware and software equipment, and with the aim of sustainable environmental development, this aspect is assessed through the two subaspects, i.e., environmental operational performance and environmental management performance, based on studies by Papadopoulos and Giama [2] and Chien and Shih [12]. A list of the operational definitions of the study variables is shown in Table 1.

\subsection{Questionnaire Design}

In this study, data was collected primarily through a questionnaire survey. The questionnaire in the study design was divided into three parts. The first part measured stakeholders' environmental awareness, relationship trust, regenerative innovation, environmental operational performance, and environmental management performance. The second part consisted of the basic information of organizations, which included questions about the measurement of the type of waste being treated, partnership maintenance type, partnership maintenance duration, age of organization, and number of company employees. The third part consisted of the basic information of interviewees, including questions about gender, age, length of service, job position, education level, and individual average monthly income. There were a total of 20 questions in the questionnaire covering the five aspects in this study, which were based on relevant past studies and revised based on the characteristics and needs of the industry in this study. Among them, there were eight questions about stakeholder environmental awareness, based on the study of Henriques and Sadorsky [10], two questions about relationship trust, based on the studies of Morgan and Hunt [11], Doney and Cannon [34], and Cheng [35], four questions about regenerative innovation, based on the studies of Rehfeld et al. [36], Lin et al. [5] and Paton and McLaughlin [6], three questions about environmental operational performance, based on the studies of Papadopoulos and Giama [2] and Chien and Shih [12], and three questions about environmental management performance, based on the studies of Papadopoulos and Giama [2] and Chien and Shih [12]. The questionnaire was measured on a five-point Likert scale, for which the degree of agreement was divided into the following: strongly disagree, disagree, neutral, agree, and strongly agree, and scored on a scale of 1 to 5 points.

\subsection{Data Collection}

The questionnaire respondents were employees of industrial waste disposal and treatment facilities in the six special municipalities of Taiwan. According to statistical data from the monthly report on the number of licensed and privately operated waste disposal and treatment facilities of the Environmental Protection Administration of the Executive Yuan (as of November 2015), there are a total of 3892 disposal facilities (Class A, B, and C) and 180 treatment facilities (Class A and B) in Taiwan. The statistics for the disposal facilities in the six special municipalities are as follows: 391 disposal facilities in Taipei City; 671 in New Taipei City; 466 in Taoyuan City, 473 in Taichung City; 304 in Tainan City; and 567 in Kaohsiung City. The statistics for the treatment facilities of the six special municipalities are as follows: 1 treatment facility in Taipei City; 8 in New Taipei City; 40 in Taoyuan City, 14 in Taichung City; 13 in Tainan City; and 54 in Kaohsiung City.

A total of 1000 questionnaires were distributed in this study, of which 956 were distributed to disposal facilities and 44 to treatment facilities. Out of the questionnaires was distributed to disposal facilities of the six special municipalities, 130 were distributed to facilities in Taipei City (including overseas export facilities), 224 to New Taipei City, 155 to Taoyuan City, 157 to Taichung City, 101 to Tainan City, and 189 to Kaohsiung City. Out of the questionnaires distributed to treatment facilities of the six special municipalities, 1 was distributed to facilities in Taipei City (including overseas export facilities), 2 to New Taipei City, 14 to Taoyuan City, 5 to Taichung City, 4 to Tainan City, and 18 to Kaohsiung City. Among these, 550 were recovered, of which 539 were valid, with an effective recovery rate of $53.9 \%$.

In summary, the number of questionnaires was based on the number of registered employees at the disposal and treatment facilities of the six special municipalities. Since the participants in this 
study were engaged in the relevant industries, three modes of distribution, i.e., field visits, mail, and phone calls, were conducted simultaneously. The questionnaires were filled out by staff at or above the executive level in each organization (including licensed waste disposal or treatment staff); one questionnaire was filled out by each organization.

\section{Descriptive Statistics of Samples}

Among the valid samples, most of the respondents were male, i.e., $98.3 \%$. In terms of age, the proportion of respondents aged between 41 and 50 years was the highest, i.e., $46.6 \%$. In terms of length of service, the proportion of respondents who worked for between 16 and 20 years was the highest. In terms of job position, senior executives accounted for $78.1 \%$. In addition, the proportion of respondents with an average individual monthly income ranging between NT\$40,000 and NT\$50,000 was the highest (see Appendix A, Table A1).

According to statistics on the basic information of relevant organizations, waste metals accounted for the highest proportion of type of waste treated, at about $89.8 \%$. In terms of partnership maintenance type, diversified relationships accounted for the highest proportion, at about $93.7 \%$. In terms of partnership maintenance duration, a duration of 16-20 years accounted for the highest proportion, at about $36.2 \%$. The average age of the organizations was 26.86 years. The average number of company employees was 11.24 (see Appendix A, Table A2).

The main study participants were the executives of industrial waste facilities and licensed waste disposal or treatment staff. A Harman [37] one-factor test was used to detect problems through common method variance (CMV). By examining the extracted factors through factor analysis without axial rotation, it is possible to determine whether or not CMV is severe. The first principle component is the most suitable for reflecting the CMV value. When several factors are obtained from this test, but the first of these explains the main variance of the independent and dependent variables, this study may be said to have severe CMV. The factor analysis method was applied in this study, in which a factor was extracted when the eigenvalue was greater than 1 without rotating the axis, and a total of 6 factors could be extracted. The first principal component explained $7.81 \%$ of variations, indicating that the first principal component did not explain the main variance of the independent and dependent variables. This means that the data sources are not severely distorted and that there is no severe CMV problem.

\section{Empirical Results}

\subsection{Measurement Model}

In terms of reliability, Table 2 shows that the load factors of the measurement indicators for the five latent aspects all reached a significant level, and that the measurement error variance did not present any negative values. The most commonly used indicators were evaluated based on the recommendations of Bagozzi and Yi [38], as described below. (1) Individual item reliability of observation variables: The reliability of an individual item is an evaluative measurement for the construction reliability of its latent variable and whether or not each load has statistical significance. The factor loads in this study all reached statistically significant levels. (2) Composite reliability (CR) of latent variables: This refers to the combined reliability value of the latent variables, which is the composite of the reliability values of all measurement variables; it indicates that the aspect indicators have internal consistency, i.e., the higher the reliability, the higher the consistency of these indicators. The CR value should ideally be above 0.60 [39]. Except for regenerative innovation and environmental management performance, which had $C R$ values below 0.60 , the $C R$ values for the remaining aspects in this study ranged between 0.625 and 0.858 , which are within the acceptable range. (3) Average variance extracted (AVE) of latent variables: This calculates the explanatory power of latent variables for the variation in all of the measurement variables. The higher the AVE value, the higher the reliability and convergent validity of the latent variables. Fornell and Larcker [39] suggested that the AVE value 
should ideally be above 0.50 . It can be seen from Table 2 that the AVE values of regenerative innovation, environmental operational performance, and environmental management performance were all below 0.50 , while those of the remaining two aspects both exceeded the threshold of 0.50 , indicating that the internal structural fit of this study model is still less than ideal.

Table 2. Analysis of scale reliability, load, and average variance extracted.

\begin{tabular}{|c|c|c|c|c|c|c|}
\hline Variable & $\begin{array}{l}\text { Load } \\
\text { (Nonstand }\end{array}$ & $\begin{array}{l}\text { Load } \\
\text { (Standardi }\end{array}$ & $\begin{array}{c}\text { Error } \\
\text { Variance }\end{array}$ & $\begin{array}{l}\text { Measurem } \\
\text { Variable } \\
\text { Reliability }\end{array}$ & $\begin{array}{l}\text { Composite } \\
\text { Reliability } \\
\text { (CR) }\end{array}$ & $\begin{array}{c}\text { Average } \\
\text { Variance } \\
\text { Extracted (AVE) }\end{array}$ \\
\hline Stakeholder environmental awareness & & & & & 0.688 & 0.529 \\
\hline Internal stakeholders & 0.068 & 0.061 & 0.255 & 0.004 & & \\
\hline Socioeconomic stakeholders & 0.415 & 0.362 & 0.241 & 0.131 & - & - \\
\hline Market stakeholders & 1.000 & 0.767 & 0.147 & 0.589 & & \\
\hline Relationship trust & & & & & & \\
\hline Honesty and trustworthiness & 0.441 & 0.442 & 0.342 & 0.195 & 0.858 & 0.777 \\
\hline Task fulfillment & 1.000 & 0.999 & 0.001 & 0.998 & & \\
\hline Regenerative innovation & & & & & & \\
\hline Production innovation & 1.000 & 0.079 & 0.250 & 0.006 & 0.203 & 0.085 \\
\hline Management innovation & 1.788 & 0.151 & 0.218 & 0.023 & & \\
\hline Service innovation & 2.397 & 0.193 & 0.236 & 0.637 & & \\
\hline Operational performance & & & & & & \\
\hline Management procedures & 1.000 & 0.319 & 0.409 & 0.102 & 0.625 & 0.366 \\
\hline Maintenance operations & 1.549 & 0.522 & 0.297 & 0.273 & & \\
\hline Facility design & 1.562 & 0.490 & 0.358 & 0.240 & & \\
\hline Management performance & & & & & ( 477 & 0254 \\
\hline Management information & 1.000 & 0.428 & 0.331 & 0.183 & 0.477 & 0.254 \\
\hline Production cost & 0.962 & 0.393 & 0.374 & 0.155 & & \\
\hline Sustainable operations & 0.393 & 0.172 & 0.374 & 0.030 & & \\
\hline
\end{tabular}

In terms of validity, the load of standardized factors in this study all reached significant levels, indicating that there is convergent validity (Table 3). In terms of discriminant validity, Fornell and Larcker [39] suggested that if the square root of the AVE of each aspect is greater than the correlation coefficient of the variable pairs of other aspects, this indicates that there is a good discriminant validity among the various aspects (Table 3). Most of the values satisfied this standard, indicating that the scales in this study have discriminant validity.

Table 3. Discriminant validity analysis of each aspect.

\begin{tabular}{cccccc}
\hline Latent Variables & $\begin{array}{c}\text { Environmental } \\
\text { Awareness }\end{array}$ & $\begin{array}{c}\text { Relationship } \\
\text { Trust }\end{array}$ & $\begin{array}{c}\text { Regenerative } \\
\text { Innovation }\end{array}$ & $\begin{array}{c}\text { Operational } \\
\text { Performance }\end{array}$ & $\begin{array}{c}\text { Management } \\
\text { Performance }\end{array}$ \\
\hline Environmental awareness & 0.727 & - & - & - & - \\
Relationship trust & 0.118 & 0.881 & - & - & - \\
Regenerative innovation & 0.607 & 0.005 & 0.292 & - & - \\
Operational performance & 0.065 & 0.005 & 0.107 & 0.605 & 0.564 \\
Management performance & 0.530 & 0.044 & 0.873 & 0.504 \\
\hline
\end{tabular}

Gray highlight indicates the square root of the AVE value of the aspect.

\subsection{Empirical Analysis of Structural Equation Model}

We used maximum likelihood (ML) to estimate the parameters. The method of Hair et al. [40] was used to divide the fit of the overall model into three types: absolute fit measures, incremental fit measures, and parsimonious fit measures. The measures are explained as follows. (1) Absolute fit measures: This is used to determine the degree to which the overall model can be used to predict covariance or phase matrix. Table 4 shows that the Chi-squared value of this study was 200.678 $(p=0.001)$, which indicates that the theoretical model and information structure of the observation 
data were inconsistent. Although it is not a good fit, the high sensitivity of the Chi-squared value to the sample size [41] allowed for the values of $\chi^{2} / d f$, GFI, RMR, and RMSEA in this study to fall within the acceptable range. (2) Incremental fit measures: This is used to compare the theoretical model and null model developed. Based on the incremental fit measures shown in Table 4, AGFI in this study was greater than 0.90. (3) Parsimonious fit measures: This is also known as adjusted fit measures, and is used to determine the degree of fit for every estimated parameter to reach consistency. Based on the parsimonious fit measures shown in Table 4, PNFI was 0.495 , which is close to 0.5 , and PGFI was 0.669 , which is greater than 0.5 ; in other words, both fall within the acceptable range. In summary, the fit of the model in this study is still less than ideal.

Table 4. Table of fitness indices for theoretical model.

\begin{tabular}{cccc}
\hline \multicolumn{2}{c}{ Test Statistic } & Standard of Perfect Fit & Study Result \\
\hline Absolute Fit Measures & $\chi^{\mathbf{2}}(\boldsymbol{p}$-value $)$ & The Smaller the Better & $\mathbf{2 0 0 . 6 7 8}(\boldsymbol{p}=\mathbf{0 . 0 0 1})$ \\
\hline- & $\chi^{2} / d f$ & Less than 5 & 2.712 \\
- & $G F I$ & Greater than 0.90 & 0.949 \\
- & $R M R$ & The smaller the better & 0.022 \\
& $R M S E A$ & $\begin{array}{c}\text { The smaller the better, } \\
\text { ideally less than } 0.05\end{array}$ & 0.056 \\
\hline Incremental fit measures & AGFI & Greater than 0.90 & 0.928 \\
- & NFI & Greater than 0.90 & 0.609 \\
- & CFI & Greater than 0.90 & 0.700 \\
\hline Parsimonious fit & m & Greater than 0.50 & 0.495 \\
- & $P G F I$ & Greater than 0.50 & 0.669 \\
\hline
\end{tabular}

The empirical results of the structural equation model are shown in Table 5 and Figure 2. The estimated coefficient of the impact of relationship trust on regenerative innovation was -0.010 , which did not reach a significant level. Therefore, hypothesis H1 in this study was not supported. This shows that relationship trust had no significant and positive impact on regenerative innovation. $\mathrm{Chu}$ and Chou [42] explored the impact of organizational trust on the performance of innovative product development in their study, and showed that organizational trust can have a differential impact on different innovative products. As the cost of regenerative innovation is high, and the projects requiring innovation are diverse, a business organization will evaluate its own conditions, select the regenerative innovation model that is most beneficial to the organization, and invest differently in different innovative products. However, this usually differs from the needs of stakeholders (comprehensive innovation), thus generating conflict and affecting trust.

Table 5. Structural coefficient estimation results of theoretical hypothetical models.

\begin{tabular}{ccccc}
\hline $\begin{array}{c}\text { Corresponding } \\
\text { Hypothesis }\end{array}$ & Relationship between Variables & $\begin{array}{c}\text { Estimated } \\
\text { Coefficient }\end{array}$ & $\begin{array}{c}\text { Standard } \\
\text { Deviation }\end{array}$ & $\begin{array}{c}\text { Supported or } \\
\text { Unsupported }\end{array}$ \\
\hline Hypothesis 1 & Relationship trust $\rightarrow$ Regenerative innovation & -0.010 & 0.050 & Unsupported \\
Hypothesis 2 & Relationship trust $\rightarrow$ Environmental awareness & $0.083^{* *}$ & 0.039 & Supported \\
Hypothesis 3 & Environmental awareness $\rightarrow$ Regenerative innovation & $0.053^{* *}$ & 0.025 & Supported \\
Hypothesis 4 & Regenerative innovation $\rightarrow$ Management performance & $5.618^{* *}$ & 1.505 & Supported \\
Hypothesis 5 & Regenerative innovation $\rightarrow$ Operational performance & 0.577 & 0.710 & Unsupported \\
Hypothesis 6 & Operational performance $\rightarrow$ Management performance & $0.602^{* *}$ & 1.222 & Supported \\
\hline
\end{tabular}




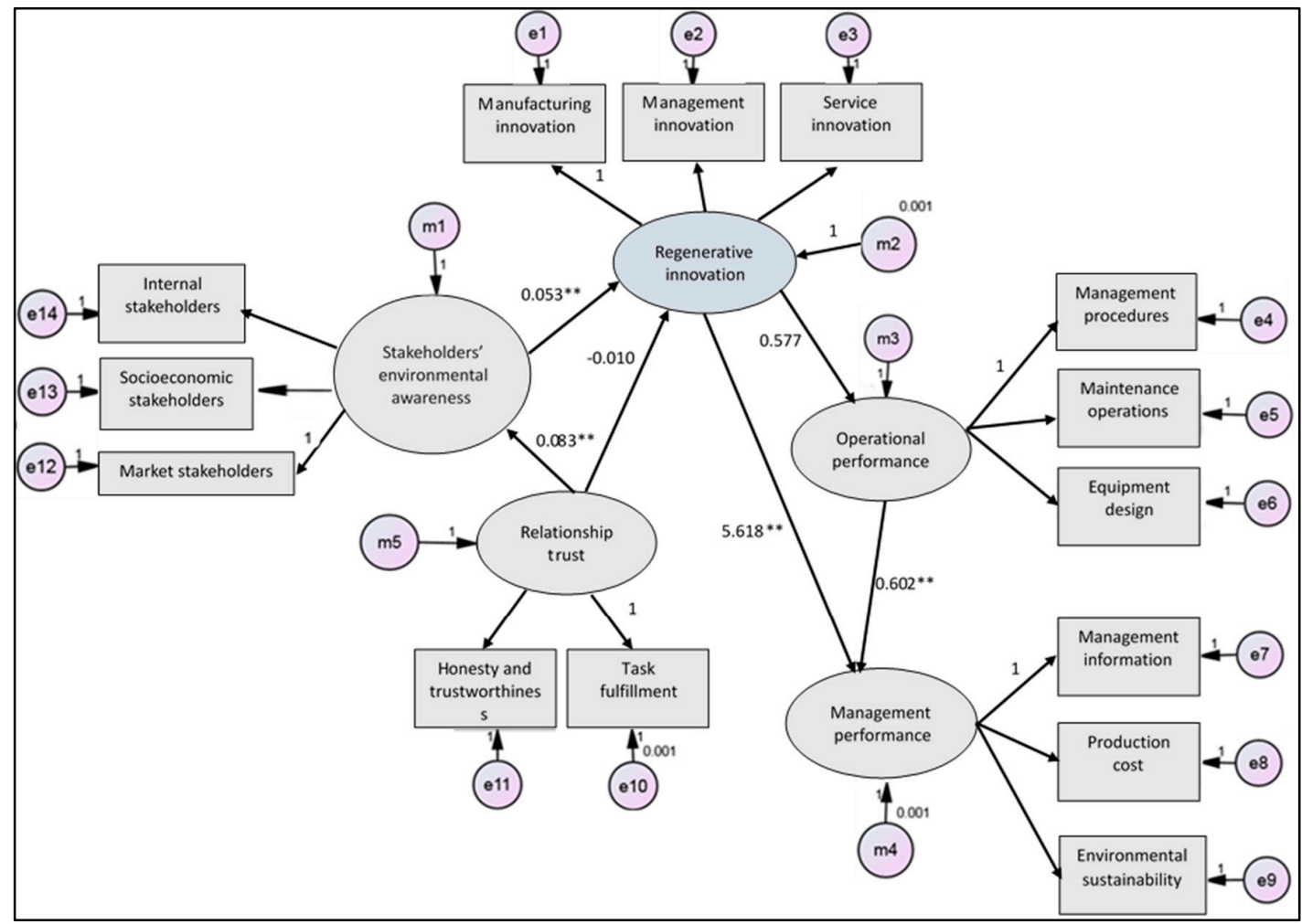

Figure 2. Estimation results of environmental performance by linear structural equation model. Remarks: e denotes the measurement error; $m$ denotes the structural equation error.

The estimated coefficient of the impact of relationship trust on stakeholder environmental awareness was 0.083 , which reached a significant level of $5 \%$. This indicates that relationship trust had a significant and positive impact on stakeholder environmental awareness. Therefore, Hypothesis $\mathrm{H} 2$ in this study was supported. When relationship trust between companies and stakeholders is established in relation to environmental awareness, this can effectively improve business efficiency, in turn bringing about good community and neighborhood relationships, as well as improving corporate brand reputation [43].

The estimated value of the impact of stakeholder environmental awareness on regenerative innovation was 0.053 , which reached a significant level of $5 \%$. This indicates that stakeholder environmental awareness had a significant and positive impact on regenerative innovation. Therefore, hypothesis $\mathrm{H} 3$ in this study was supported. As external stakeholders are the main source of influence on the environmental management of the waste industry, among whom residents and environmental protection organizations exert the largest impact, this is sufficient to exert a major influence on company operations and lead policy makers to adjust their environmental management policies, thereby moving towards regenerative innovation and R\&D [10].

The estimated coefficient for the impact of regenerative innovation on environmental management performance was 5.618, which reached a significant level of 5\%. This indicates that regenerative innovation had a significant and positive impact on environmental management performance. Therefore, hypothesis $\mathrm{H} 4$ in this study was supported. The impact of green innovation on environmental management performance was investigated by studying manufacturers with Taiwan's ISO 14001 certification; the results showed that there was a positive relationship between innovative production operations and active administrative management with environmental performance [27].

The estimated coefficient for the impact of regenerative innovation on environmental operational performance was 0.577 , which did not reach a significant level. Therefore, hypothesis $\mathrm{H} 5$ in this study was not supported. This indicates that regenerative innovation had no significant and positive impact 
on environmental operational performance. Given the uncertainty of the environment, whether or not regenerative innovation can be carried out through organizational strategies and management is subject to influences from changes in the external environment. In practice, there is a certain limit to the effects of the regenerative innovation projects undertaken by the industrial waste industry. As these come under the mode of operations of small and medium enterprises, there is still some distance to cover before a systematic business model can be established. Furthermore, as the types of waste are too diverse, business organizations can only carry out follow-up regenerative innovation in registered projects, so the parts that require high expenditure on management procedures, maintenance operations, and equipment design will take a back seat. Especially in light of the general economic downturn, business organizations will only carry out operations and management for the parts that are beneficial to the business and are necessary to implement. The process of formulating dynamic environmental management and operational procedures in a timely and opportune manner presents a certain degree of difficulty. It was speculated that this was also a cause for the absence of a significant impact.

Lastly, the estimated coefficient for the impact of environmental operational performance on environmental management performance was 0.602 , which reached a significant level of $5 \%$. Therefore, hypothesis $\mathrm{H} 6$ in this study was supported. This indicates that environmental operational performance had a significant and positive impact on environmental management performance. As the industry begins to specify necessary environmental management and operational procedures, maintenance operations are being implemented, and subsequent $R \& D$, innovation, and design all begin to align with the established goals, and subsequent environmental management can then reduce costs and move towards a sustainable industry [33].

\section{Conclusions and Recommendations}

In order to expand on the scope of research on partnership governance, the partnership relationship was analyzed by exploring the impact of stakeholder environmental awareness on company regenerative innovation using a linear structural equation model. A theoretical framework and models were constructed following a literature review. A goodness of fit test of the linear structural model showed that the overall theoretical model in this study reached acceptable levels, indicating that the theoretical model in this study could be supported.

The empirical results showed that relationship trust had a significant and positive impact on stakeholder environmental awareness. This means that when there is more relationship trust, stakeholder environmental awareness better aligns with company awareness, which can bring about good communication relationships and enhance companies' reputations [43]. Stakeholder environmental awareness had a significant and positive impact on regenerative innovation. As stakeholders are part of the interactive relationships with companies, they can provide important resources to the organization and increase the company's willingness to engage in innovation and $R \& D$, thereby improving production efficiency [44]. Relationship trust does not have a direct and significant impact on regenerative innovation; rather, this impact is mediated by stakeholder environmental awareness.

Regenerative innovation had a significant and positive impact on environmental management performance, which means that environmental management is helpful towards improving the disclosure of environmental management information, and can effectively reduce production costs [12]. When the industry management and operational procedures can be modified dynamically and in a timely manner, environmental operational and management performance can be effectively improved [33]. Regenerative innovation had no significant and positive impact on environmental operational performance. Hence, the impact of regenerative innovation on environmental management performance is not mediated by environmental operational performance.

This study showed that: (1) relationship trust had a significant impact on stakeholder environmental awareness; (2) stakeholder environmental awareness had a significant impact on regenerative innovation; (3) regenerative innovation had a significant impact on environmental 
management performance; and (4) environmental operational performance had a significant impact on environmental management performance. This shows that the relevance and influence of the various aspects within the organizations of the industrial waste industry are consistent with those of other industries, that is, relationship trust will affect companies' willingness to engage in regenerative innovation through stakeholder environmental awareness. However, environmental operational performance must be flexible, and the model for formulating the operations must be revised in a timely and relevant manner to align it with the overall environment and enable it to achieve industrial and environmental business efficiency.

This study mainly conducted empirical analyses of the various relationship factors of organizations within the industrial waste industry in Taiwan. In terms of recommendations for subsequent studies, if external and global variables can be included, such as international environmental protection policies and overseas protectionism, this will be more helpful towards the practical development of industry organizations. Trust involves interactions among all the participants in a market. Such interactions are affected by depth and time, as the establishment of trust involves long-term interactions, and changes with time. However, since this study obtained its data by means of a questionnaire, it was difficult to resample the fixed sample to obtain long-term data. In this study, 539 waste management companies in the six special municipalities were analyzed; we did not perform any comparisons with international counterparts. Different countries or regions could have different cultural perceptions and management performance with respect to waste management. Therefore, precautions should be taken if the results of this study are to be applied in other countries or regions.

Author Contributions: W.-C.Y. is the main idea and writing of the thesis. M.-H.T. is the inspiration of the concept. C.-C.L. provides research methods. C.Y. collects research data. All authors have read and agreed to the published version of the manuscript.

Funding: This research received no external funding.

Acknowledgments: We would like to thank our three academic advisors for their eager assistance, valuable suggestions, and corrections which greatly contributed to the content integrity of this study.

Conflicts of Interest: The authors declare no conflict of interest.

\section{Appendix A}

Table A1. Basic data of respondents.

\begin{tabular}{cccccc}
\hline \multirow{3}{*}{ Gender } & Number of & Pamples & Percentage & $\begin{array}{c}\text { Effective } \\
\text { Percentage }\end{array}$ & $\begin{array}{c}\text { Cumulative } \\
\text { Percentage }\end{array}$ \\
\hline \multirow{5}{*}{ Age } & Male & 530 & 98.3 & 98.3 & 98.3 \\
& Female & 9 & 1.7 & 1.7 & 100 \\
\hline \multirow{4}{*}{ Length of service } & Under 21 & 1 & 0.2 & 0.2 & 0.2 \\
& $21-30$ & 14 & 2.6 & 2.6 & 2.8 \\
& $31-40$ & 157 & 29.1 & 29.1 & 31.9 \\
& $41-50$ & 251 & 46.6 & 46.6 & 78.5 \\
& $51-60$ & 93 & 17.3 & 17.3 & 95.7 \\
& Above 60 & 23 & 4.3 & 4.3 & 100 \\
\hline \multirow{3}{*}{ Occupation } & Below 5 years (inclusive) & 17 & 3.2 & 3.2 & 3.2 \\
& $6-10$ years & 56 & 10.4 & 10.4 & 13.5 \\
& $11-15$ years & 153 & 28.4 & 28.4 & 41.9 \\
& $16-20$ years & 242 & 44.9 & 44.9 & 86.8 \\
& 21-30 years & 36 & 6.7 & 6.7 & 93.5 \\
& Above 31 years & 35 & 6.5 & 6.5 & 100 \\
\hline
\end{tabular}


Table A1. Cont.

\begin{tabular}{|c|c|c|c|c|c|}
\hline & & $\begin{array}{c}\text { Number of } \\
\text { Samples }\end{array}$ & Percentage & $\begin{array}{c}\text { Effective } \\
\text { Percentage }\end{array}$ & $\begin{array}{l}\text { Cumulative } \\
\text { Percentage }\end{array}$ \\
\hline \multirow{3}{*}{ Education level } & Junior high school or below & 44 & 8.2 & 8.2 & 8.2 \\
\hline & Junior college & 116 & 21.5 & 21.5 & 90.2 \\
\hline & $\begin{array}{c}\text { Two/four-year technical program } \\
\text { or university }\end{array}$ & 49 & 9.1 & 9.1 & 99.3 \\
\hline \multirow{5}{*}{$\begin{array}{l}\text { Average individual } \\
\text { monthly income }\end{array}$} & NT\$20,000-NT\$30,000 & 0 & 0 & 0 & 0 \\
\hline & NT $\$ 40,000-N T \$ 50,000$ & 239 & 44.3 & 44 & 44 \\
\hline & NT $\$ 60,000-N T \$ 70,000$ & 209 & 38.8 & 38.8 & 83.3 \\
\hline & NT\$80,000-NT\$90,000 & 32 & 5.9 & 5.9 & 89.2 \\
\hline & Above NT $\$ 100,000$ & 58 & 10.8 & 10.8 & 100 \\
\hline
\end{tabular}

Table A2. Basic data of facilities.

\begin{tabular}{|c|c|c|c|c|c|}
\hline & & $\begin{array}{l}\text { Number of } \\
\text { Samples }\end{array}$ & Percentage & $\begin{array}{l}\text { Effective } \\
\text { Percentage }\end{array}$ & $\begin{array}{l}\text { Cumulative } \\
\text { Percentage }\end{array}$ \\
\hline \multirow{5}{*}{ Type of waste treated } & Waste metals & 484 & 89.8 & 89.8 & 89.8 \\
\hline & Cinders and liquids & 11 & 2.0 & 2.0 & 96.8 \\
\hline & Animal and plant waste & 8 & 1.5 & 1.5 & 98.3 \\
\hline & Construction/wood/paper waste & 5 & 0.9 & 0.9 & 99.3 \\
\hline & Others & 0 & 0 & 0 & 0 \\
\hline \multirow{3}{*}{ Partnership maintenance type } & Vertical relationship & 3 & 0.6 & 0.6 & 0.6 \\
\hline & Horizontal relationship & 26 & 4.8 & 4.8 & 5.4 \\
\hline & Cross-field relationship & 5 & 0.9 & 0.9 & 6.3 \\
\hline \multirow{2}{*}{$\begin{array}{l}\text { Partnership maintenance } \\
\text { duration }\end{array}$} & $16-20$ years & 195 & 36.2 & 36.2 & 70.7 \\
\hline & Above 21 years & 158 & 29.3 & 29.3 & 100 \\
\hline \multirow{3}{*}{$\begin{array}{c}\text { Age of organization } \\
\text { Number of company employees }\end{array}$} & & Average & $\begin{array}{l}\text { Standard } \\
\text { deviation }\end{array}$ & Minimum & Maximum \\
\hline & - & 26.86 & 7.15 & 12.00 & 56.00 \\
\hline & - & 11.24 & 5.47 & 3.00 & 31.00 \\
\hline
\end{tabular}

\section{References}

1. Sharma, S. Managerial interpretations and organizational context as predictors of corporate choice of environmental strategy. Acad. Manag. J. 2000, 43, 681-697.

2. Papadopoulos, A.M.; Giama, E. Environmental performance evaluation of thermal insulation materials and its impact on the building. Build. Environ. 2007, 42, 2178-2187. [CrossRef]

3. Bloom, N.; Draca, M.; Reenen, J.V. Trade Induced Technical Change? The Impact of Chinese Imports on Innovation, IT, and Productivity. Rev. Econ. Stud. 2016, 83, 87-117.

4. Porter, M.E.; van der Linde, C. Green and competitive. Harv. Bus. Rev. 1995, 73, 120-134.

5. Lin, R.J.; Chen, R.H.; Chiu, K.S. Customer relationship management and innovation capability: An empirical study. Ind. Manag. Data Syst. 2010, 110, 111-133. [CrossRef]

6. Paton, R.A.; McLaughlin, S. Services innovation: Knowledge transfer and the supply chain. Eur. Manag. J. 2008, 30, 77-83. [CrossRef]

7. Freeman, R.E. Strategic Management: A Stakeholder Approach; Pitman: Boston, MA, USA, 1984.

8. Frooman, J. Stakeholder influence strategies. Acad. Manag. Rev. 1999, 24, 91-205. [CrossRef]

9. Elkington, J. Towards the sustainable corporation: Win-win-win business for sustainable Development. Calif. Manag. Rev. Winter 1994, 36, 90-100. [CrossRef] 
10. Henriques, I.; Sadorsky, P. The relationship between environmental commitment and managerial perceptions of stakeholder importance. Acad. Manag. J. 1999, 42, 87-99.

11. Morgan, R.M.; Hunt, S.D. The commitment-trust theory of relationship marketing. J. Market. 1994, 58, $20-38$. [CrossRef]

12. Chien, M.K.; Shih, L.H. An empirical study of the implementation of green supply chain management practices in the electrical and electronic industry and their relation to organizational performances. Int. J. Environ. Sci. Technol. 2007, 4, 383-394.

13. Yeh, W.C.; Tseng, M.H.; Lee, C.C. The relationship between transaction costs, resource dependency, social networks, partnerships, and organizational performance in the industrial waste management industry. J. Stat. Manag. Syst. 2018, 21, 417-454. [CrossRef]

14. Ik-Whan, G.K.; Taewon, S. Factors affecting the level of trust and commitment in supply chain relationships. J. Supply Chain Manag. 2004, 40, 4-14.

15. Brown, B.; Butler, J.E. Competitors as allies: A study of entrepreneurial networks in the U.S. wine industry. J. Small Bus. Manag. 1995, 33, 57-66.

16. Kao, M.J.; Huang, I.C. A study on the relationship between green management and stakeholders: Empirical analysis of the 1000 largest manufacturing industries in Taiwan. Sun Yat Sen Manag. Rev. 2000, 8, 537-565.

17. Henriques, I.; Sadorsky, P. The determinants of an environmentally responsive firm: An empirical approach. J. Environ. Econ. Manag. 1996, 30, 381-395. [CrossRef]

18. Gulati, R. Does familiarity breed trust? The implications of repeated ties for contractual choices in alliances. Acad. Manag. J. 1995, 38, 85-112.

19. Jap, S.D. Perspectives on joint competitive advantages in buyer-supplier relationships. Int. J. Res. Market. 2001, 18, 26. [CrossRef]

20. Schilling, M.A. Strategic Management of Technological Innovation, 2nd ed.; McGraw Hill: New York, NY, USA, 2008.

21. Macher, J.T.; Mowery, D.C. Measuring dynamic capabilities: Practices and performance in semiconductor manufacturing. Br. J. Manag. 2009, 20, 41-62. [CrossRef]

22. Abernathy, W.J.; Kim, C.B. Innovation: Mapping the winds of creative destruction. Res. Policy 1985, 14, 3-22. [CrossRef]

23. Hung, S.C.; Liu, T.H. The impact of budget participation on R\&D managers' product innovation performance: Effects of trust, job satisfaction, and information Asymmetry. J. Inf. Soc. 2002, 2, 185-203.

24. Cheng, K.C.; Chen, C.S.; Shih, N.S. Impact of budget participation in product innovation performance: Effects of trust, job satisfaction, and information asymmetry. Asia Pac. Manag. Rev. 2014, 19, 132-150.

25. Frank, L.J.; Richard, R. Trust and adaptation in relational contracting. Acad. Manag. Rev. 2000, 25, 873-882.

26. Petts, J.A.H. Environmental responsiveness, individuals and organizational learning: SME experience. J. Environ. Plan. Manag. 1998, 41, 711-730. [CrossRef]

27. Kao, M.J.; Huang, I.C.; Chang, N.J. Impact of green innovation on environmental performance and economic performance. J. Environ. Manag. 2009, 10, 88-104.

28. Klassen, R.D.; Whybark, D.C. The impact of environmental technologies on manufacturing performance. Acad. Manag. J. 1999, 42, 599-615.

29. Fan, M.F.; Chiu, C.M. Predicaments and opportunities for industrial waste governance: The case of agricultural land pollution in Qishan District. Taiwan J. Polit. 2019, 23, 1-41.

30. Nehrt, C. Maintainability of first mover advantages when environmental regulations differ between countries. Acad. Manag. Rev. 1998, 23, 77-97. [CrossRef]

31. Berry, M.A.; Rondinelli, D.A. Proactive corporate environmental management: A new industrial revolution. Acad. Manag. Exec. 1998, 12, 38-50. [CrossRef]

32. Shrivastava, P. Environmental technologies and competitive advantage. Strat. Manag. J. 1995, 16, $183-200$. [CrossRef]

33. Hutchinson, C. Corporate strategy and the environment. Long Range Plan. 1992, 25, 9-21. [CrossRef]

34. Doney, P.M.; Cannon, J.P. An examination of the nature of trust in buyer-seller Relationships. J. Market. 1997, 61, 35-51.

35. Cheng, J.W. Qualitative Research on Interpersonal Trust Models; National Science Council of the Executive Yuan: Taipei, Taiwan, 2004. 
36. Rehfeld, K.M.; Rennings, K.; Ziegler, A. Integrated product policy and environmental product innovations: An empirical analysis. Ecol. Econ. 2007, 61, 91-100. [CrossRef]

37. Harman, H.H. Modern Factor Analysis; University of Chicago Press: Chicago, IL, USA, 1967.

38. Bagozzi, R.P.; Yi, Y. On the evaluation of structural equation models. J. Acad. Market. Sci. 1988, 16, 74-79. [CrossRef]

39. Fornell, C.; Larcker, D.G. Evaluating structural equation models with unobservable variables and measurement error. J. Market. Res. 1981, 18, 39-50. [CrossRef]

40. Hair, J.F.; Black, W.C.; Babin, B.J.; Anderson, R.E.; Tatham, R.L. Multivariate Data Analysis, 5th ed.; Prentice Hall International: Upper Saddle River, NJ, USA, 1998.

41. Chiu, H.C. Quantitative Research and Statistical Analysis; Wu-Nan Culture Enterprise: Taipei, Taiwan, 2006.

42. Chu, M.; Chou, C.L. A Study on Innovation Network Relationships and New Product Development Performance Based on Organizational Trust. In Proceedings of the 12th Conference on Science and Technology and Integrated Management; Springer: Cham, Switzerland, 2008; pp. 277-293.

43. Hess, J.; Story, D. Trust-based commitment: Multidimensional consumer-brand Relationships. J. Consum. Market. 2005, 22, 313-322. [CrossRef]

44. Shen, M.C. A Study on correlations between the impact of stakeholders on strategy and governance mechanisms and performance. Fu Jen Manag. Rev. 2004, 11, 1-32.

(C) 2020 by the authors. Licensee MDPI, Basel, Switzerland. This article is an open access article distributed under the terms and conditions of the Creative Commons Attribution (CC BY) license (http://creativecommons.org/licenses/by/4.0/). 